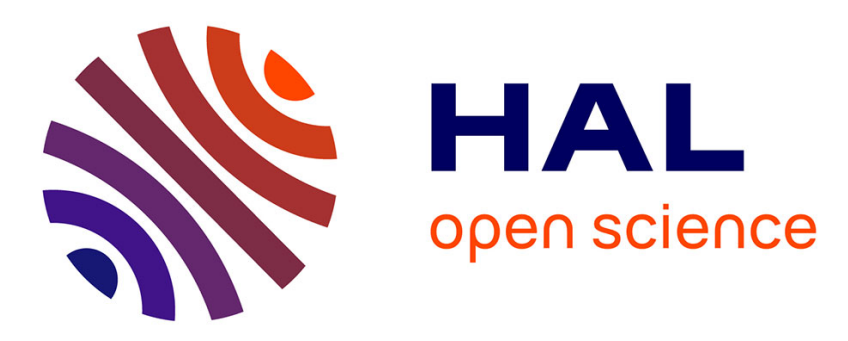

\title{
Experimental analysis of masonry infilled frames using digital image correlation
}

Néstor Guerrero, Manuel Martinez, Ricardo Picon, Maria Eugenia Marante, François Hild, Stéphane Roux, Julio Florez-Lopez

\section{- To cite this version:}

Néstor Guerrero, Manuel Martinez, Ricardo Picon, Maria Eugenia Marante, François Hild, et al.. Experimental analysis of masonry infilled frames using digital image correlation. Materials and structures, 2014, 47 (5), pp.873-884. 10.1617/s11527-013-0099-0 . hal-00974365

\section{HAL Id: hal-00974365 \\ https://hal.science/hal-00974365}

Submitted on 6 Apr 2014

HAL is a multi-disciplinary open access archive for the deposit and dissemination of scientific research documents, whether they are published or not. The documents may come from teaching and research institutions in France or abroad, or from public or private research centers.
L'archive ouverte pluridisciplinaire HAL, est destinée au dépôt et à la diffusion de documents scientifiques de niveau recherche, publiés ou non, émanant des établissements d'enseignement et de recherche français ou étrangers, des laboratoires publics ou privés. 


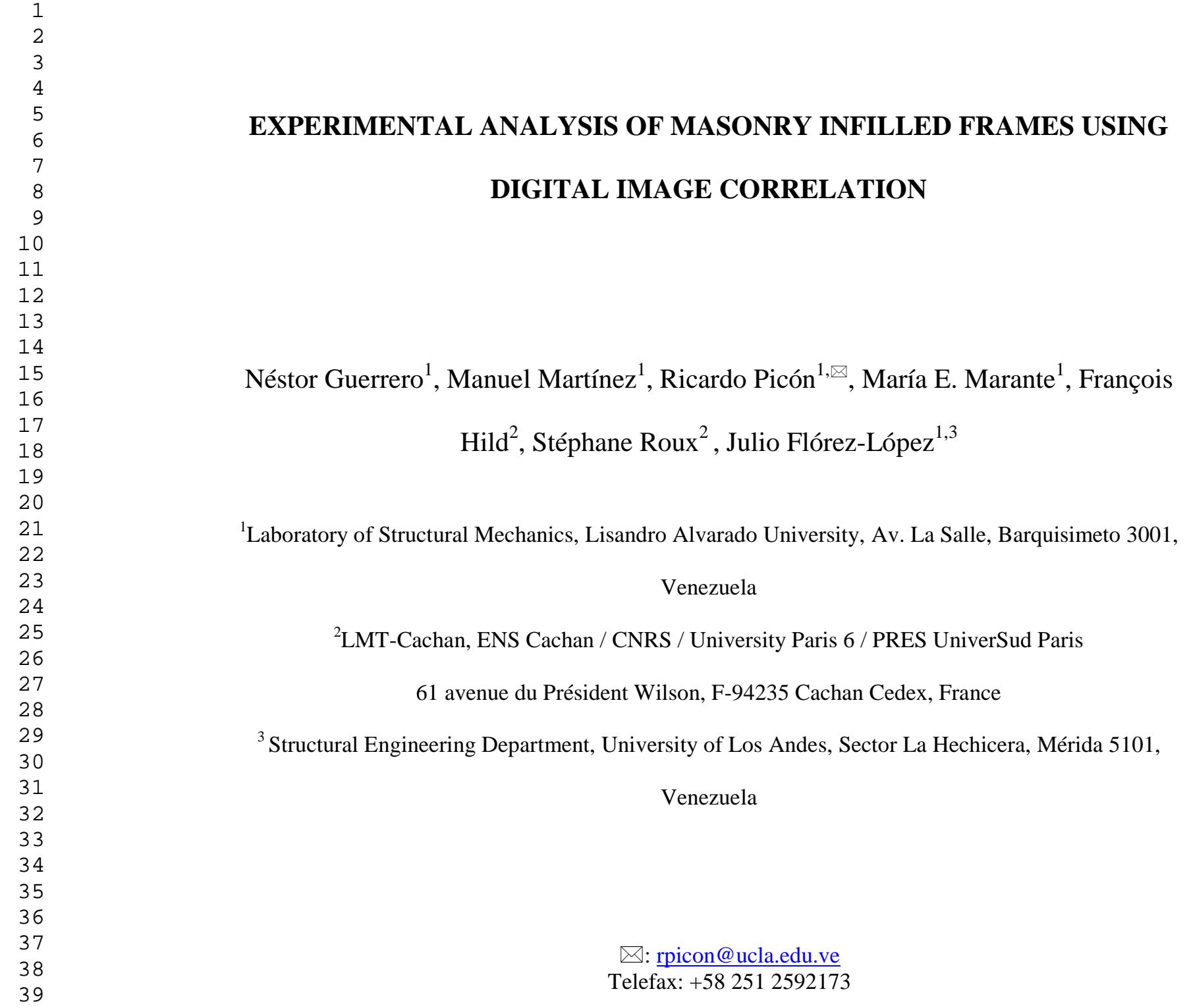

\section{EXPERIMENTAL ANALYSIS OF MASONRY INFILLED FRAMES USING DIGITAL IMAGE CORRELATION}

\author{
Néstor Guerrero ${ }^{1}$, Manuel Martínez ${ }^{1}$, Ricardo Picón ${ }^{1, \bigotimes}$, María E. Marante ${ }^{1}$, François \\ Hild $^{2}$, Stéphane Roux ${ }^{2}$, Julio Flórez-López ${ }^{1,3}$ \\ ${ }^{1}$ Laboratory of Structural Mechanics, Lisandro Alvarado University, Av. La Salle, Barquisimeto 3001, \\ Venezuela \\ ${ }^{2}$ LMT-Cachan, ENS Cachan / CNRS / University Paris 6 / PRES UniverSud Paris \\ 61 avenue du Président Wilson, F-94235 Cachan Cedex, France \\ ${ }^{3}$ Structural Engineering Department, University of Los Andes, Sector La Hechicera, Mérida 5101, \\ Venezuela
}

$\triangle:$ rpicon@ucla.edu.ve Telefax: +582512592173 


\begin{abstract}
A measurement technique (Digital Image Correlation) is used for a critical evaluation of simplified models for infilled framed structures. It allows for the assessment of displacement and strain fields in the panel of interest. Several specimens, including infilled and partially infilled frames were subjected to cyclic lateral loads. It was found that two very different deformation mechanisms appear in the masonry panels namely, a first one during the hardening phase and another one, completely different, during the softening stage. For the former, strain concentration bands are observed. After the peak load, horizontal bands appear in the middle of the panels. The Polyakov assumption, i.e. that the panel can be replaced by struts in the analysis, is validated in the hardening stage. However, the orientation of the struts suggested in the literature was not found experimentally. The experimental results demonstrate that the inclination of the bands depends on the brick dimensions and arrangement. Further, the final failure mechanism corresponds to a sliding shear mode.
\end{abstract}

Keywords: Framed structures; Masonry; Models; Correlation Technique; Failure modes; Seismic behavior. 


\section{Introduction}

The necessity for including the masonry in the analysis of the global behavior of framed structures such as buildings subjected to overloads like earthquakes, settlements, impacts or explosions has been well established.

Numerous experimental studies carried out on infilled frames are reported in the literature; amongst them, let us mention those of [1-12]. These works describe tests that range from one bay-single story specimens to two bay-four story buildings [4]; many of them subjected to cyclic lateral loadings that are intended to represent seismic effects.

Asteris et al. [13] classify the failure modes observed experimentally into five categories as shown in Fig. 1.

(a)

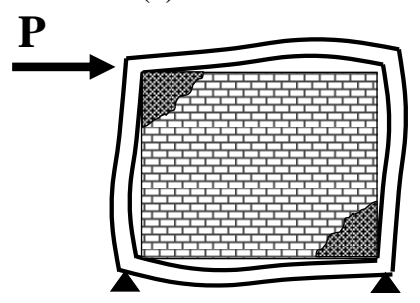

(b)

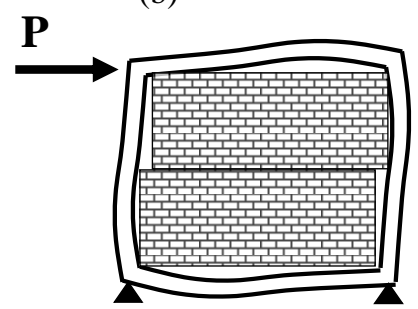

(c)

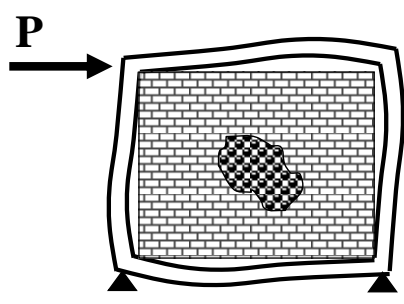

(e)

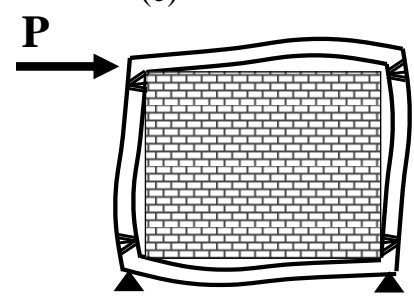

Fig. 1 Different failure modes of masonry-infilled frames: (a) Corner crushing mode; (b) Sliding shear mode; (c) Diagonal compression mode; (d) Diagonal cracking mode; (e) Frame failure mode.

A state of the art of the models for the analysis of infilled frames can be found in Asteris et al. [14]. In that paper the approaches for the modeling of the behavior of the infill frames are classified into two categories, namely micro-models [14-23] and macro-models [1-2, 13, 24-34]. In the former, the masonry is represented as a continuum discretized into numerous finite elements. Each element 
describes in a very detailed way the heterogeneous nature of the material degradation; in some cases using homogenization techniques, or even including distinct sub-elements for each material of the infill. In the later approach, the infill is usually substituted by a single diagonal strut, or a set of them. The micro approach gives a rich description of the phenomena taking place in the infill under overloads including the interface between frames and infill [15]. The corresponding models intend to consider all possible failure modes, but their use is limited to very simple structures due to the complexity of the analysis and the large amount of data that is collected. For large structures such as buildings, any of the aforementioned macro models is usually chosen. Very simple and schematic results are obtained in that case, generally describing only one or two failure modes [13], but they are considered accurate enough for engineering purposes.

The case of the infill frames with openings has been deeply studied because of the complexities involved [13, 35-37]. The modes of failure of infilled frames with openings are far more complex than those of solid infill panels. The multiple-strut models provide better modeling of both the infill and its interaction with the RC frame, but cannot be used in general purpose finite element software because of the complexities involved in their implementation [13]. The modeling of the masonry infill with openings is still an open subject and require further study imperative [37].

In this work, the macro approaches are experimentally evaluated. The difference between this study and the aforementioned ones is the use of Digital Image Correlation (DIC) to enrich the experimental database. When this technique is used, the specimen surface is prepared in order to create a random texture. The specimen is loaded and digital pictures are taken at some predetermined intervals. The pictures are subsequently analyzed by using a correlation software (CORRELI-Q4 in present case) [38] that determines displacement and strain fields with respect to some reference image as described in the third section of the paper. The use of the DIC technique gives objective and quantitative data of the amount and location of strain and cracking concentrations. As a result, the strut approach is validated although not in the way that has been proposed in any of the references cited in the paper. 
The experimental tests and the kinematic measurements obtained using the DIC technique are described in the fourth section of the paper and the critical evaluation of the different macro-models is given in the last section.

The observations presented in this paper can be used in the development of new and simpler models that might describe the masonry behavior in a more precise way.

\section{Simplified approaches for masonry analyses}

The substitution of the masonry panel by a single diagonal strut element was proposed in the pioneering work by Polyakov [25], as it is shown in Fig. 2. In the case of cyclic loadings, the infilled panel is represented by two diagonal strut bars.
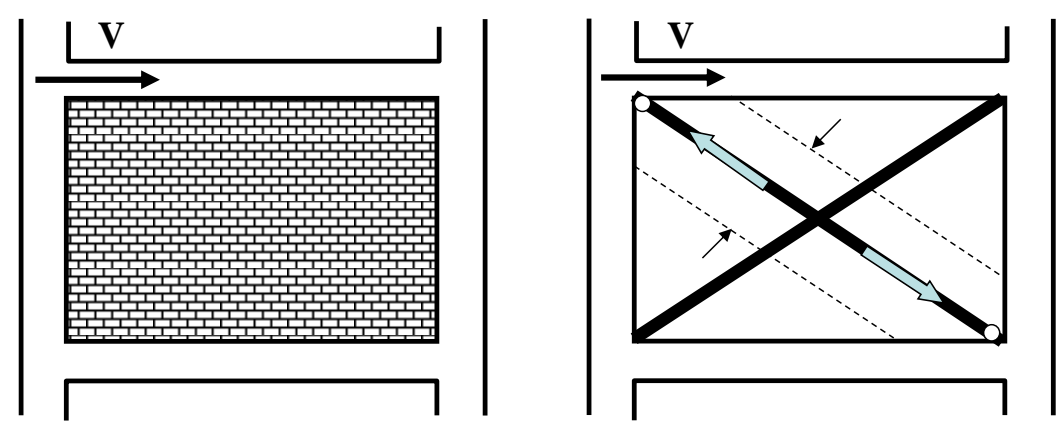

Fig. 2 Diagonal strut model

Zarnic and Tomazevic [27] proposed a modified version of Polyakov's model. The diagonal strut is connected to the frame at some distance of the beam-column joint such as indicated in Fig. 3. The justification of this modification was that the damage in the upper part of the panels, in some tests, occurred far from the diagonal. 
(a)

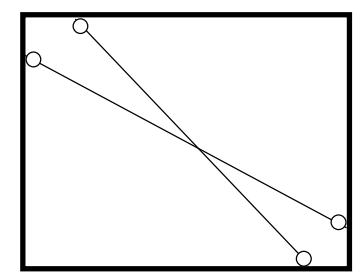

(c)

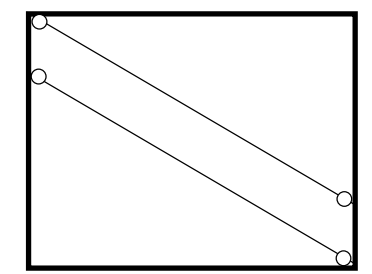

(b)

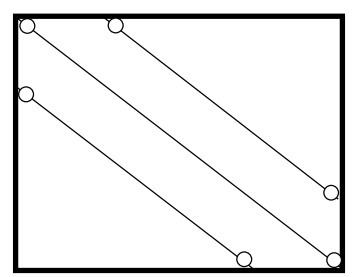

Fig. 3 Zarnic and Tomazevic's model [27]

The introduction of multiple struts in each direction has also been proposed [1, 24, 28,30 and 39]. The descriptions given in those references are shown in Fig. 4 and Fig. 5.

(a)

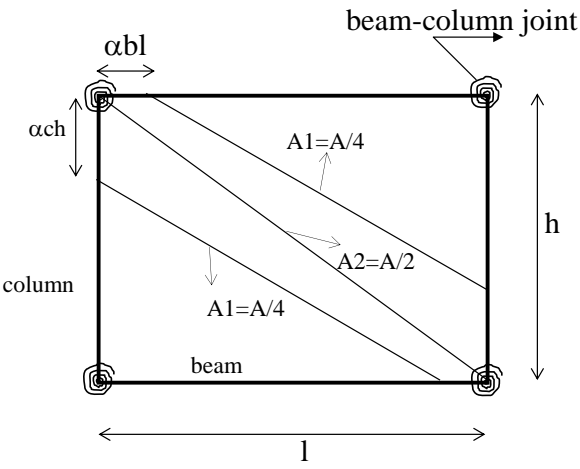

(b)

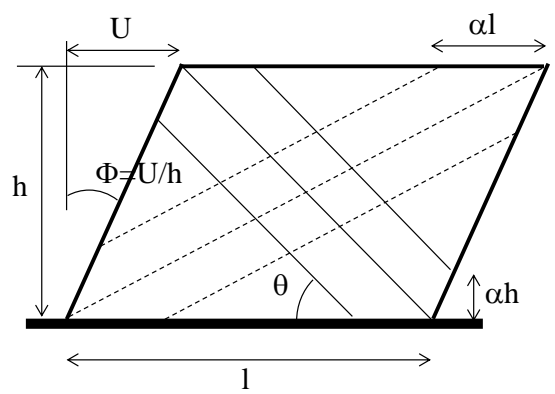

Fig. 5 Multiple struts models according to (a) El-Dakhakhni et al. [24]; (b) Chrysostomou et al. [28] 


\section{Digital image correlation technique}

Digital image correlation is applicable to a wide range of nano and micro [40-41], meso [42] and macro scales [43]. Digital image correlation is an optical method to measure displacements on an object surface [42] or in the bulk [44-45] by comparing the object texture at different states, usually one before loading and the other one after being deformed. The displacement field, for example of a planar object, has two in-plane components, say $u$ and $v$, and one out-of plane component, $w$. The two in-plane displacement components are directly computed by digital image correlation. Subsequently, the displacement gradients are then derived by spatial differentiation of the displacement field data. More details regarding this approach are provided by [38, 40-46].

\section{Experimental analysis of confined and partially confined masonry walls}

\section{Single bay infilled frame (IF1)}

The results of four specimens tested at the Laboratory of Structural Mechanics of Lisandro Alvarado University [47-48] are presented in this work. The first one, referred to as IF, is a one-bay infilled frame as shown in Fig. 6(a). The specimen was subjected to prescribed cyclic displacements at the top as is shown in Fig. 6(b) and the response is presented in Fig. 7(a). A heavy concrete beam was built at the top of the frame to avoid tractions. The details of the frame are included in Appendix 1. The size of the concrete masonry blocks was $40 \times 20 \mathrm{~cm}$ with a thickness of $15 \mathrm{~cm}$. The infill was built in the standard overlapped way.

(a)

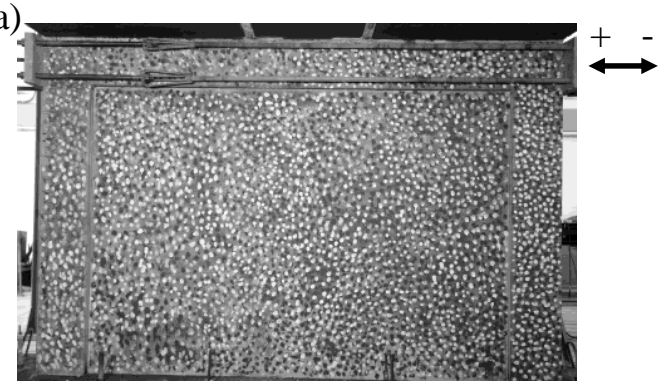

(b)

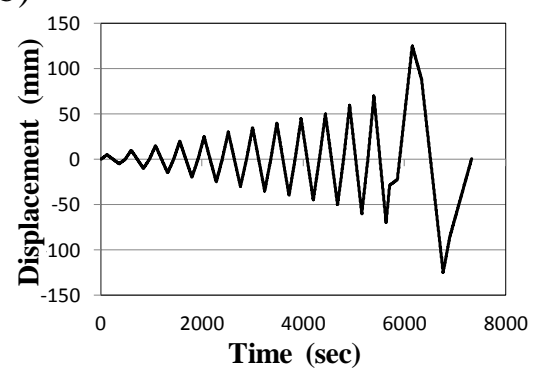

Fig. 6 (a) Single bay infilled frame (IF1); (b) History of jack displacements 
Fig. 7 shows the strain fields. In Fig. 7(b), it is possible to appreciate high levels of strains at the borders between the frame and the infill that appear at the peak of the first loading. Low strain values are observed in the remainder of the wall. Notice too that the lower left and upper right corners exhibit no significant strains. Fig. 7(c) shows the strain field when the direction of the lateral force changes. The same strain pattern is observed with a change of the unloaded corner.

(b)

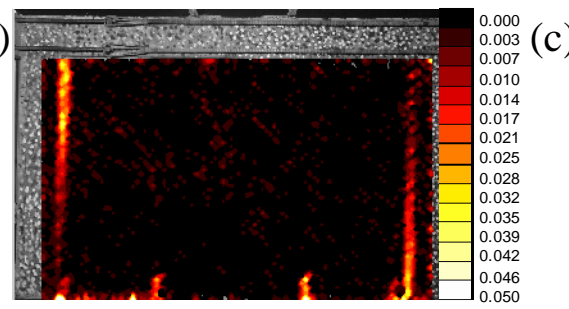

(d)

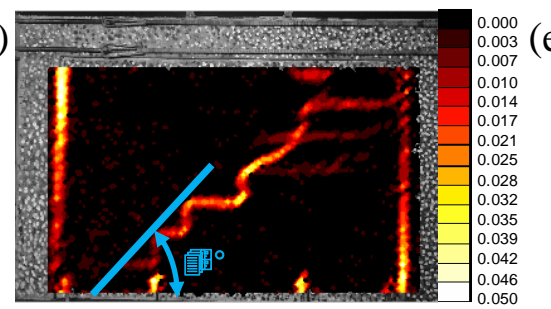

(f)

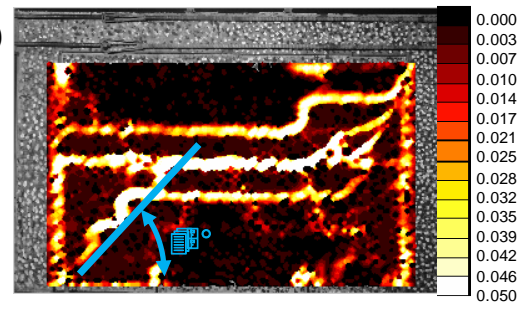

(a)

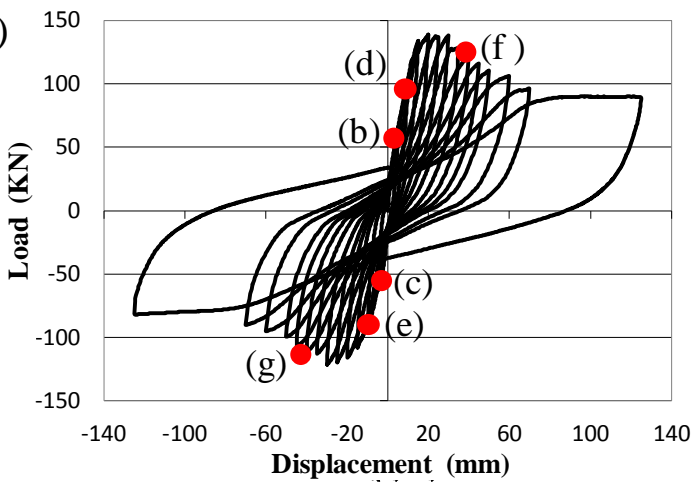

(c)

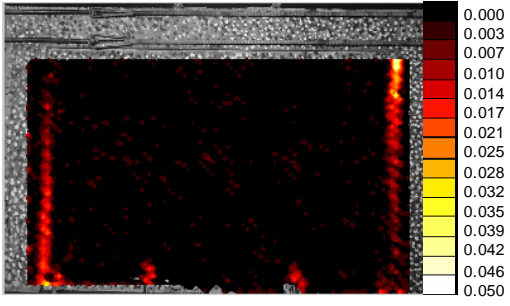

(e)

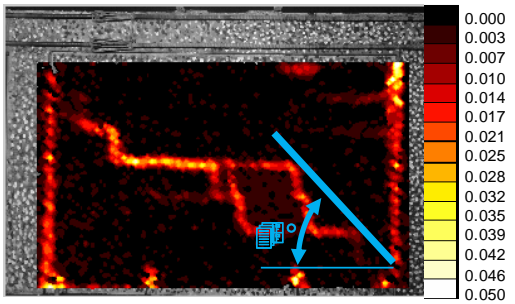

(g)

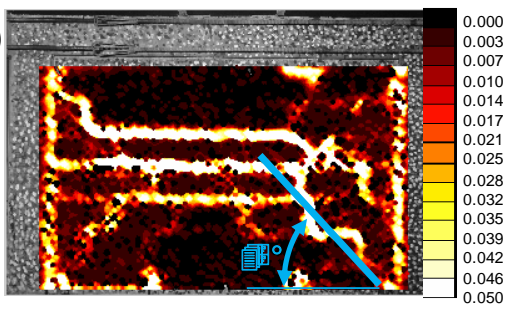

Fig. 7 Single bay infilled frame (IF1); (a) Force vs. displacement curve; (b) and (c) Strain fields in the first cycle; (d) and (e) Strain fields in the second cycle; (f) and (g) Strain fields in a subsequent cycle after the peak 
Strain fields during the second cycle are shown in Fig. 7(d) and (e). A sudden change in the deformation pattern is observed. Diagonal bands at a roughly $45^{\circ}$ angle appear in the wall for positive (Fig. 7(d)) and negative displacements (Fig. 7(e)). Fig. 7 (f) and (g) show the strain fields at a subsequent cycle after the peak of the applied force. A different pattern of deformation is observed with predominant horizontal bands with high strain levels. These bands are connected with the corners of the frame by short $45^{\circ}$ branches.

\section{Single bay partially infilled frame $(P F)$}

In the present test, the same frame was partially infilled as shown in Fig. 8 and subjected to the loading path presented in Fig. 6(b). This type of configuration is commonly found in scholar facilities in Venezuela and other tropical countries.

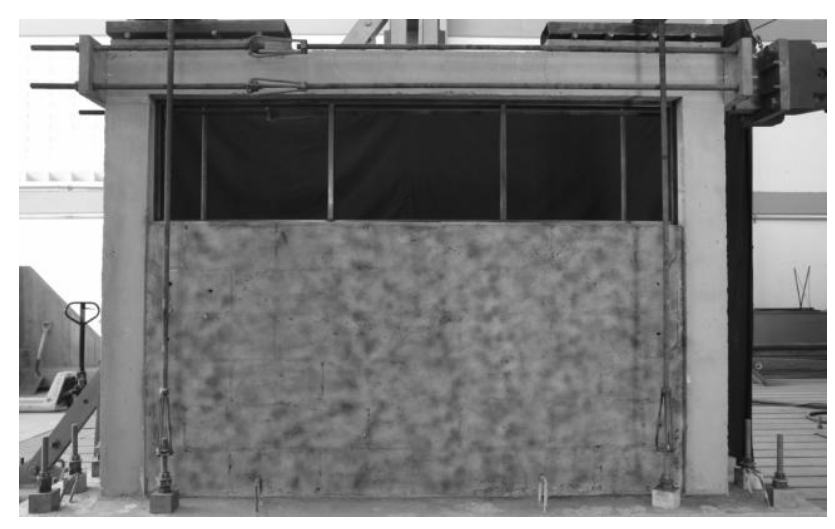

Fig. 8 Single bay partially infilled frame (PF)

The global response of the specimen is indicated in Fig. 9(a). The strain fields at the third cycle are shown in Fig. 9(b) and (c). Two different sets of diagonal bands are observed. Although the deformation pattern is complex, the bands start at the corners of the wall and follow an approximately rectilinear trajectory with a $45^{\circ}$ angle again. It is important to underline the presence of two different branches in this specimen when compared with the IF1 test. As in that test, the deformation pattern 
with diagonal bands changes to a set of predominantly horizontal branches after the loading peak as shown in Fig. 9(d) and (e).

(a)

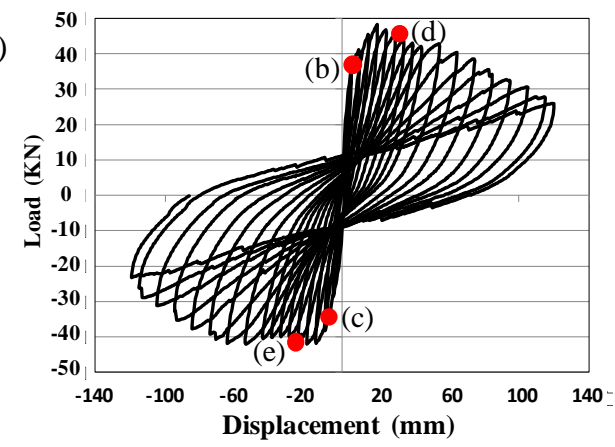

(b)
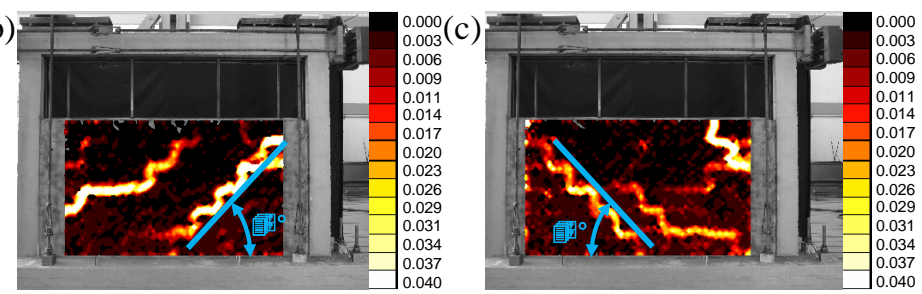

(d)
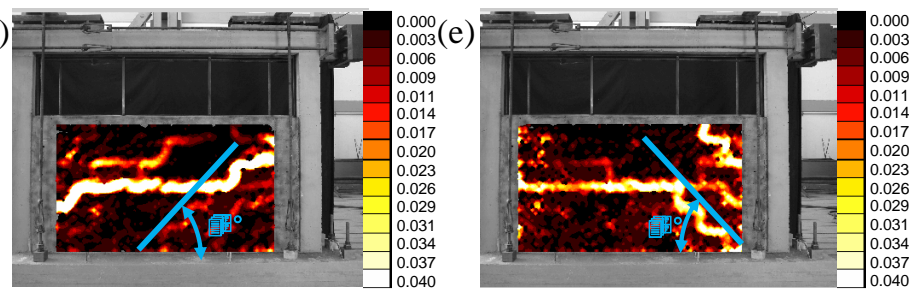

Fig. 9 Single bay partially infilled frame (PF) (a) Force vs. stroke response; (b) and (c) Strain fields in the third cycle; (d) and (e) Strain fields in a subsequent cycle after the peak

\section{Two-bay partially infilled frame $(\mathrm{TF})$}

A two-bay frame (Fig. 10), also partially infilled, was tested the same way. The details of this specimen are included in Appendix 2. The force vs. stroke curve is shown in Fig. 11(a). There were no significant differences between the deformation patterns in the PF and TF tests. The strain fields are shown in Fig. 11(b-e.) 


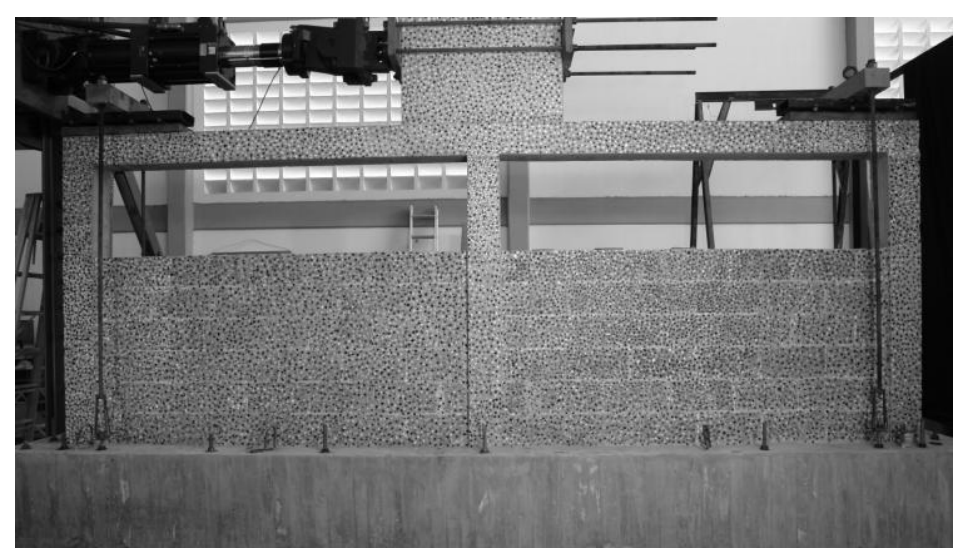

Fig. 10 Two-bay partially infilled frame (TF)

(a)

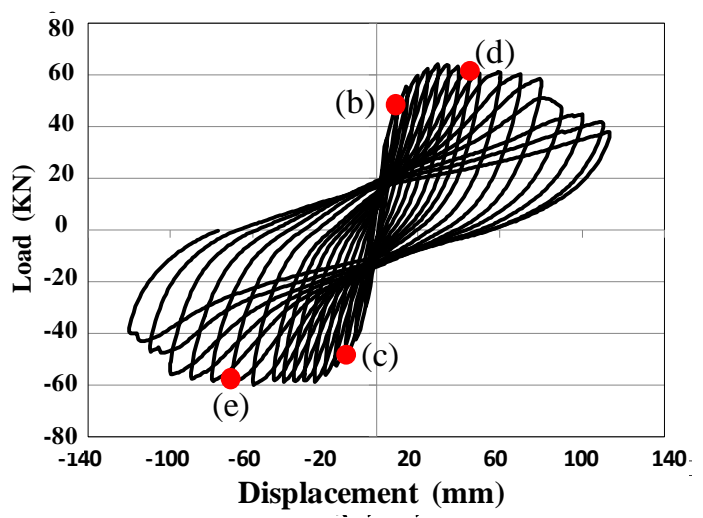

(b)

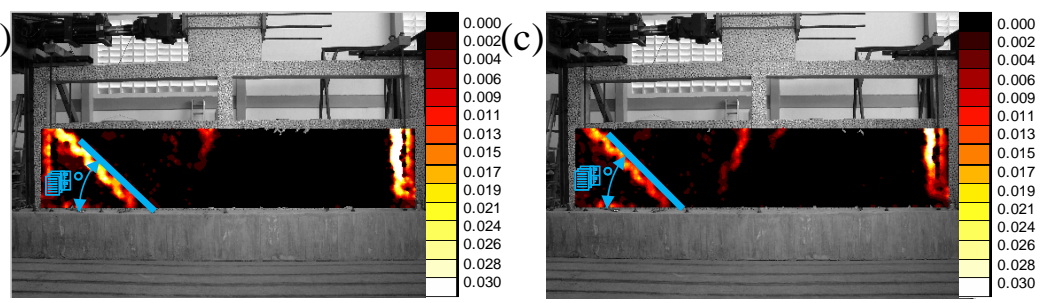

(d)

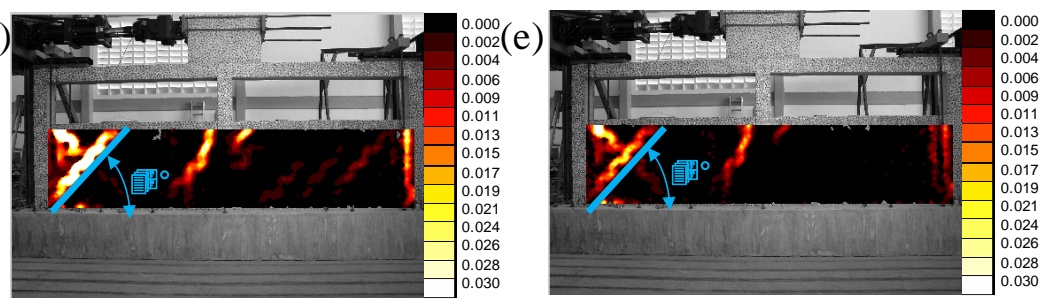

Fig. 11 Two-bay partially infilled frame (TF) (a) Force vs. stroke response; (b) and (c) Strain fields in the third cycle; (d) and (e) Strain fields in a subsequent cycle after the peak 


\section{Squat infilled frame (SF)}

It is worth noting that in the PF and TF tests there are different sets of $45^{\circ}$ bands while in the IF1 test the branch could be interpreted as a corner-to-corner strut, as usually assumed in the macro-models, but also as a $45^{\circ}$ compression band. In order to determine whether the difference in behavior is due to the aspect ratio of the wall or because of the partial confinement of the infill, a new test was carried out. A masonry wall with the same aspect ratio as the PF test, but completely confined (Fig. 12) was subjected to the same cyclic loading. As seen in Fig. 13(b), the bands at $45^{0}$ of the PF test are again observed during the first cycles. After the peak, the bands become predominantly horizontal as shown in Fig. 13(c).

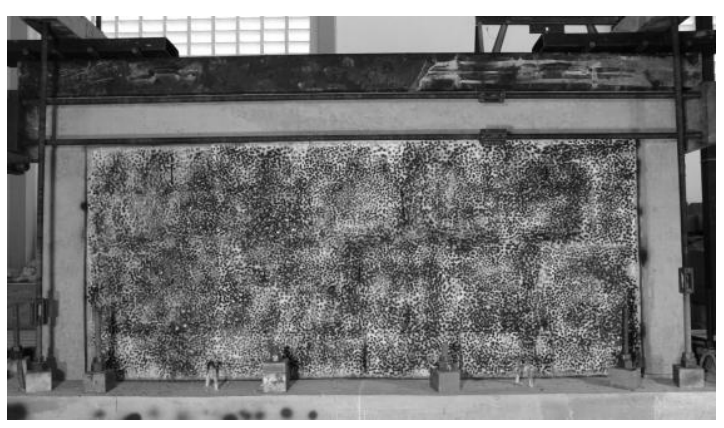

Fig. 12 Squat infilled frame (SF)

(a)

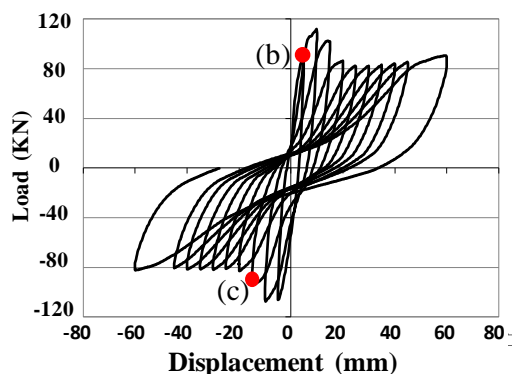

(b)

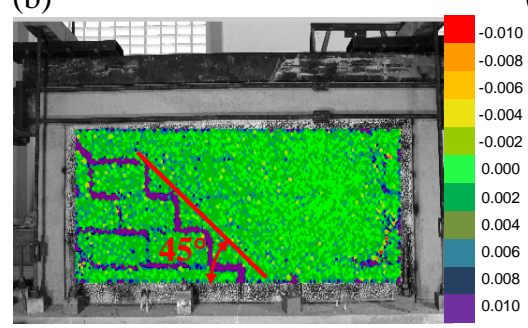

(c)

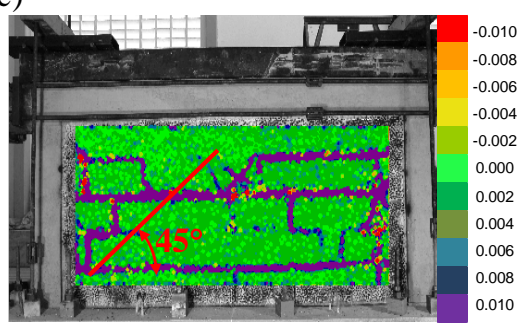


Fig. 13 Squat infilled frame (SF) (a) Force vs. stroke response; (b) Strain fields in the first cycles; (c) Strain fields in a subsequent cycle after the peak

\section{Single bay infilled frame (IF2)}

In order to evaluate the influence of the aspect ratio of the blocks in the deformation pattern, an infilled frame was built using concrete blocks of $20 \times 27 \mathrm{~cm}$ with a thickness of $15 \mathrm{~cm}$. The specimen (Fig. 14(a)) was subjected to the mono-sign loading presented in Fig. 14(b). The strain field during the test is shown in Fig. 15. As can be appreciated in this figure, several sets of diagonal bands appear in the wall but this time with an inclination of $56^{\circ}$.

(a)

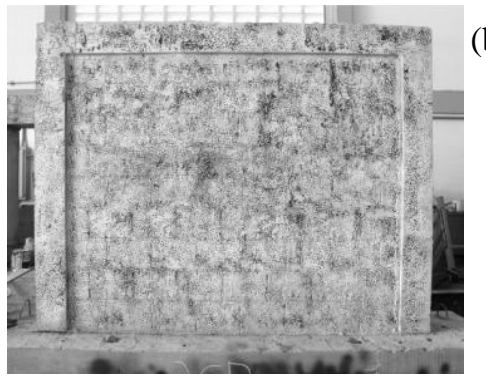

Fig. 14 (a) Single bay infilled frame (IF2) (b) History of jack displacements

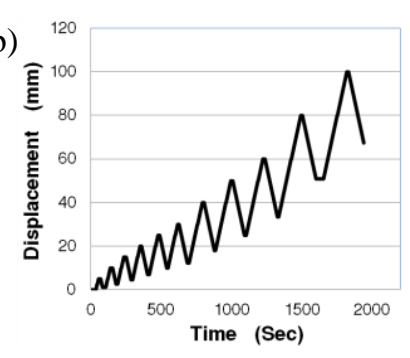




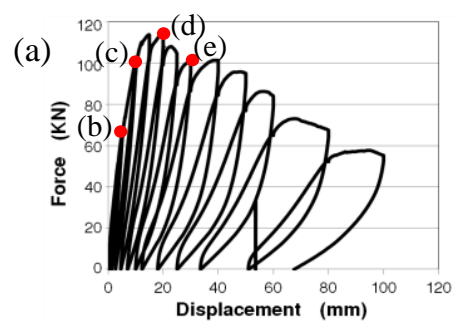

(b)

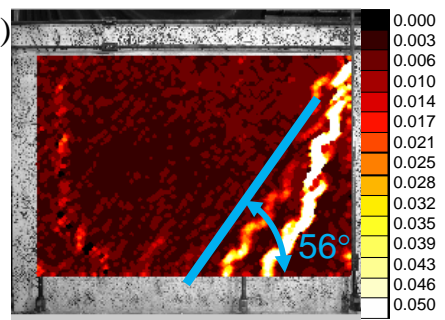

(d)

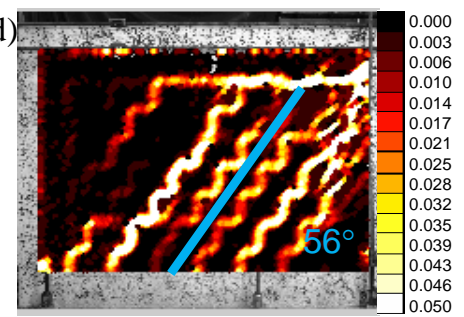

(c)

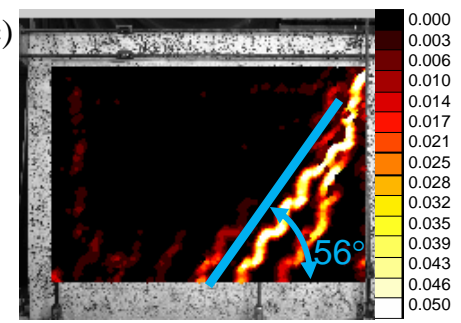

(e)

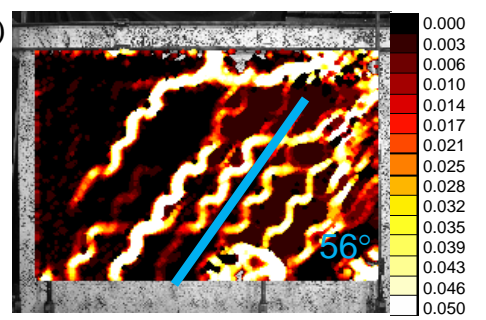

Fig. 15 Single bay infilled frame (IF2) (a) Force vs. stroke response; (b) and (c) Strain fields before the peak; (d) Strain field in the peak; (e) Strain field after the peak

\section{Evaluation of the simplified approaches and conclusions}

Two different deformation patterns were observed during the tests. In the first stage, during the hardening phase, inclined bands appeared (see for instance Fig. 7(d) and (e), Fig. 9(b) and (c), Fig. 13(b) and Fig. 15(b) and (c)). In all the tests, the end of this stage coincided with the maximum load capacity of the structure. A different pattern of bands was observed during the softening phase of the tests (see for instance Fig. 7(f) and (g), Fig. 9 (d) and (e), Fig. 13(c)). These bands were predominantly horizontal and connected to the beam-column joint by short inclined bands.

If these observations are related with the failure modes described in Fig. 1, it is interpreted that there is a shift from a predominantly diagonal compression mode of deformation to a sliding shear degradation mode. 
The use of the DIC technique confirms the validity of the Polyakov's approach but only during the hardening phase of the loading, namely, the infill masonry panel may be substituted by compression struts because concentrated strain bands are observed in the wall while the rest of it remains mildly deformed.

As proposed in some aforementioned references, more than one compression band appears in the panel. During the hardening phase of the tests, a single dominant band was observed in two cases (IF1 and TF tests); in the other three tests (IF2, PF and SF), two distinct bands are identified.

A significant difference between the DIC results and the models proposed in the literature is related to the inclination of the "struts." In the tests, the bands are oriented at approximately $45^{0}$ with respect to the horizontal line in the specimens built with blocks with aspect ratios equal to $1: 2$ and $56^{\circ}$ in the one where the aspect ratio was equal to $1: 1.5$. The struts in the model are always related to the corner to corner inclination of the wall. In walls with an aspect ratio close to one, which corresponds to most of the cases studied in laboratories, both criteria coincide. This result demonstrates that the inclination of the bands depends on the brick dimensions and arrangement.

As aforementioned, a sudden modification of the deformation pattern occurs at the beginning of the softening phase. The bands change from inclined to predominantly horizontal. In this second stage, multiple bands were observed.

Taking into account that the physics of the critical softening stage is not correctly described by the diagonal strut model, it would be interesting to develop a new macro-model based on a more realistic deformation pattern, namely, one that would be able to describe the two dominant cracking modes. On the other hand, in order to be attractive for practical applications, the formulation of the new model should not add significant mathematical complexities.

DIC could be very useful for the verification of the boundary conditions considered in the analysis performed with micro-models. As it is explained by Asteris [15], one of the main problems found in the analysis of the behavior of infilled frames under lateral load is to do a realistic estimation of the contact conditions between the infill and the RC frame. In the images, it is possible to appreciate the evolution of the contact lengths between the panel and the frame with the variation of the lateral load 
magnitude and direction. In general terms, it is observed a rapid separation between masonry and frame, remaining contact only at the corners of the diagonal. Additionally, it can be observed that there is not contact for the opposite diagonal; this fact validates the unilateral behavior hypothesis, i.e. the struts are active only when are subjected to compression stresses.

\section{Acknowledgments}

The results presented in this paper were obtained in the course of an investigation sponsored by FONACIT-ECOS NORD and CDCHT-UCLA.

\section{Appendixes}

Appendix 1

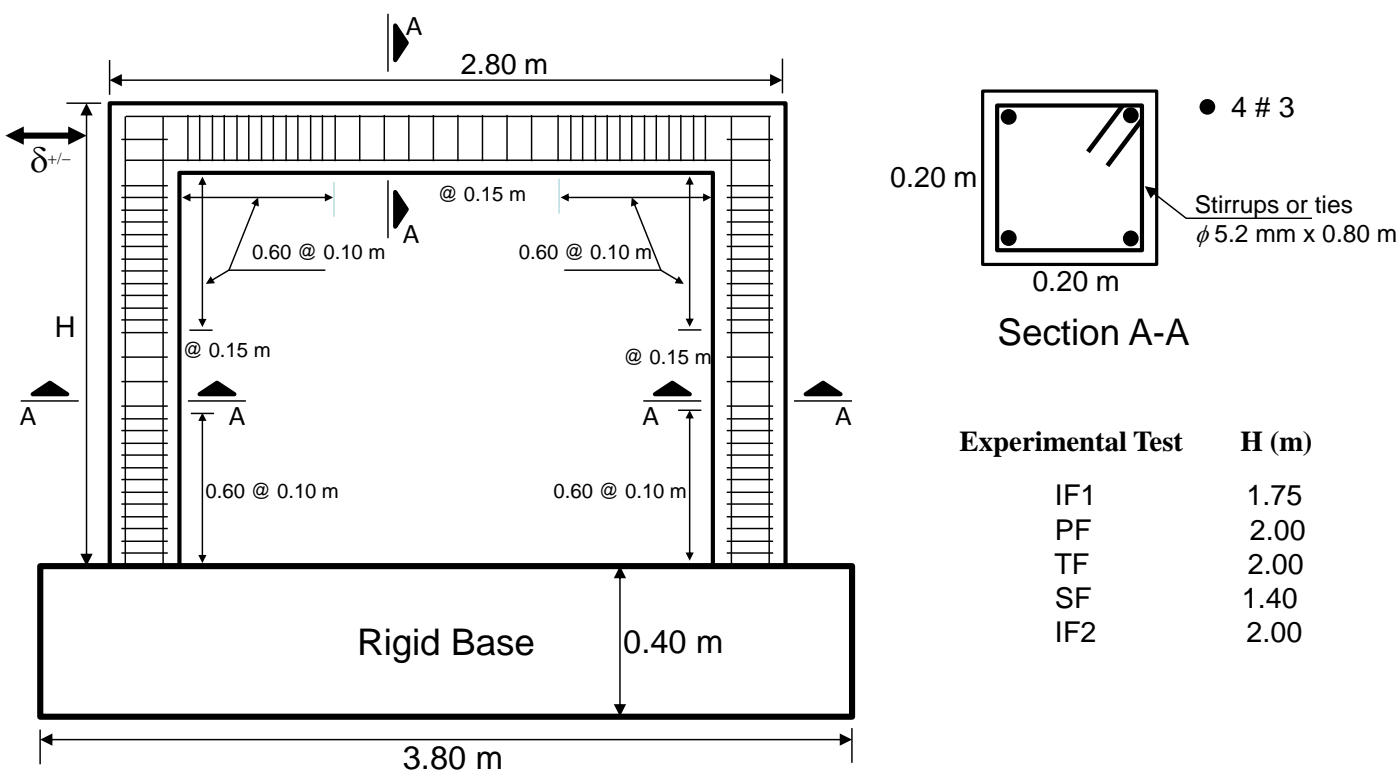

Appendix 2 


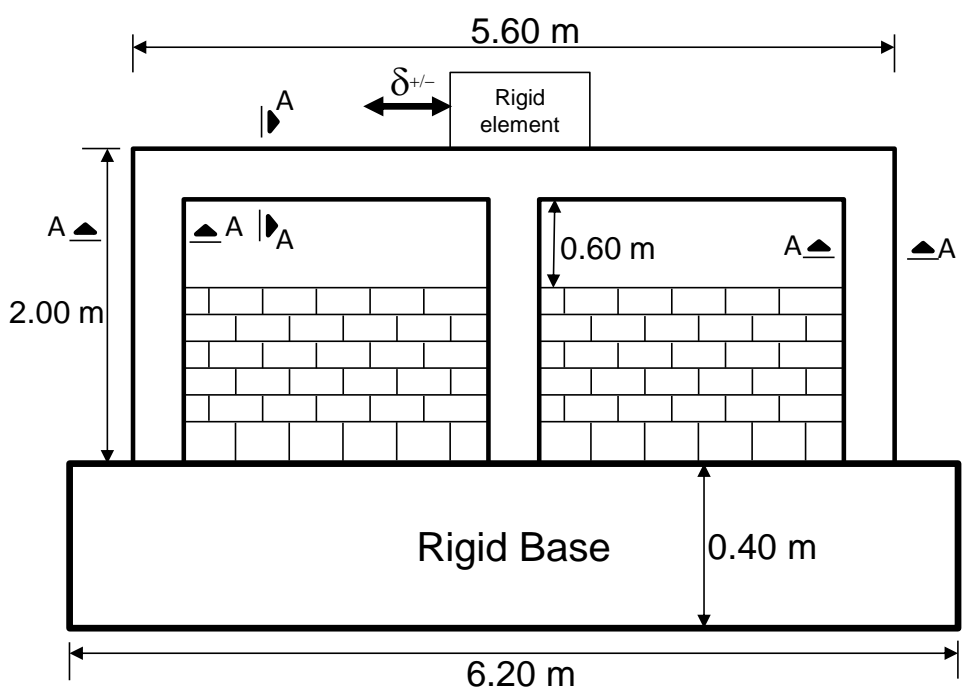

23

24

25

26

27

28

29

30

31

32

33

34

35

36

37

38

39

40

41

42

43

44

45

46

47

48

49

50

51

52

53

54

55

56

57

58

59

60

61

62

63

64

65 


\section{References}

[1] Smith BS (1966) Behavior of square infilled frames. J Struct Div 1: 381-403

[2] Smith BS, Carter C (1969) A method of analysis for infilled frames. Proc Inst Civ Eng, Struct Build, 44: 31-48

[3] Liaw TC (1979) Tests on multistory infilled frames subjected to dynamic lateral loading. J Am Concr Inst 76(4): 551-560

[4] Negro P, Anthoine A, Combescure D, Magonette G, Molina J, Pegon P. Verzeletti G (1995) Tests on the four-storey reinforced concrete frame with masonry infills: Preliminary Report. Special Publication No. 195.54. Ispra (VA), Italy

[5] Mehrabi AB, Shing PB, Schuller M, Noland J (1996) Experimental evaluation of masonry-infilled RC frames. J Struct Eng 122(3): 228-237

[6] Chiou Y, Tzeng J, Liou Y (1999) Experimental and analytical study of masonry infilled frames. J Struct Eng 1109-1117

[7] El-Dakhakhni W (2000) Experimental and analytical seismic evaluation of concrete masonryinfilled steel frames retrofitted using GFRP laminates. Electronics Theses DSpace at Drexter University Libraries

[8] Al-Chaar G, Issa M, Sweeney S (2002) Behavior of masonry-infilled nonductile reinforced concrete frames. J Struct Eng 128(8): 1055-1063

[9] Tasnimi A, Mohebkhah A (2011) Investigation on the behavior of brick-infilled steel frames with openings, experimental and analytical approaches. Eng Struct 33: 968-980

[10] Mendoza-Perez JCS, Rico-Garcia E, Flores-Corona LE (2011) Effect of connector density on shear capacity of reinforced masonry wallettes. Indian J Eng and Mat Sci 18(2): 157-160

[11] Colunga AT, Juárez A, Salinas VH (2007) Resistencia y deformación de muros de mampostería combinada y confinada sujetos a cargas laterales. Revista de Ingeniería Sísmica, Universidad Autónoma Metropolitana, México 76: 29-60

[12] Anil Ö, Altin S (2007) An experimental study on reinforced concrete partially infilled frames. Eng Struct 29: 449-460 
[13] Asteris PG, Antoniou ST; Sophianopoulos DS, Chrysostomou CZ (2011) Mathematical Macromodeling of Infilled Frames: State of the Art. J Struct Eng. 137 (12):1508-1517

[14] Asteris PG, Kyriazopoulos AD, Vouthounis PA (2002) The state-of-the-art in infilled frames numerical models. Proceedings of the Struct Eng World Congress (SEWC2002), Yokohama, Japan, October 2002, Paper No. T1-2-c2

[15] Asteris, PG (2008) Finite Element Micro-Modeling of Infilled Frames, Elec J Struct Eng. 8:1-11

[16] Marllick DV, Severn RT (1967) The behaviour of infilled frames. J Struct Div, 183-199

[17] Liauw TC, Kwan KH (1984) Nonlinear behaviour of nonintegral infilled frames. Comput Struct 18: $551-560$

[18] Papia M (1988) Analysis of infilled frames using a coupled finite element and boundary element solution scheme. Int J Numer Methods Eng 26: 731-742

[19] Haris I, Hortobagyi Z (2012) Different FEM models of reinforced concrete frames stiffened by infill masonry for lateral loads. Periodica Polytechnica-Civil Eng 56(1): 25-34

[20] Lofti HR, Shing PB (1994) Interface model applied to fracture of masonry structures. J Struct Eng 120: $63-80$

[21] Lourenço PB, Rots JG (1997) Multisurface interface model for analysis of masonry structures. J Eng Mech 123: 660-668

[22] Singh H, Paul DK, Sastry VV (1998) Inelastic dynamic response of reinforced concrete infilled frames. Comput Struct 69(6): 685-693.

[23] Van Zijl GPAG (2004) Modeling masonry shear-compression: Role of dilatancy highlighted. J Eng Mech 130: 1289-1296

[24] El-Dakhakhni W, Elgaaly M, Hamid A (2003) Three-strut model for concrete masonry-infilled steel frames. J Struct Eng 129(2): 177-185

[25] Polyakov VS (1956) Masonry in framed buildings. Godsudarstvenoe Isdatel' stvo Literatury Po Stroidal stvui Architecture, Moscow

[26] Klingner RE, Bertero VV (1976) Infilled frames in earthquake resistant construction. Report 76032, Berkeley: University of California 
[27] Zarnic R, Tomazevic M (1984) The behavior of masonry infilled reinforced concrete frames subjected to cyclic lateral loading. Proc Ninth World Conf on Earthq Eng, San Francisco, USA, VI, $863-870$

[28] Chrysotomou CZ, Gergely P, Abel JF (2002) A six-strut model for nonlinear dynamic analysis of steel infilled frames. Int J Struct Stab and Dyn, 2(3): 335-353

[29] Zarnic R (1994) Inelastic model of RC frame with masonry infilled-analytical approach. Eng Modeling 7: 47-54

[30] Crisafulli F, Carr A, Park R (2000) Analytical modeling of infilled frame structures. A general review. Bulletin of New Zealand Soc. for Earthq Eng 33(1):30-47.

[31] Rodrigues H, Varum H, Costa A (2010) Simplified Macro-Model for Infill Masonry Panels. J Earthq Eng 14(3): 390-416

[32] Zhang CQ, Zhou Y, Zhou DY, Lu XL (2011) Study on the effect of the infill walls on the seismic performance of a reinforced concrete frame. Earthq Eng and Eng Vibration 10(4): 507-517

[33] Chrysostomou CZ, Asteris PG (2012) On the in-plane properties and capacities of infilled frames. Eng Struct 41: 385-402

[34] Hak S, Morandi P, Magenes G, Sullivan TJ (2012) Damage control for clay masonry infills in the design of RC frame structures. J Earthq Eng 16(SI-1):1-35

[35] Asteris PG (2003). Lateral Stiffness of Brick Masonry Infilled Plane Frames. J Struct Eng; (ASCE), 129(8): 1071-1079

[36] Mohebkhah A, Tasnimi AA (2012). Distinct element modeling of masonry-infilled steel frames with openings. Open Const Building Tech J, 6: 42-49

[37] Asteris PG, Kakaletsis DJ, Chrysostomou CZ, Smyrou EE (2011). Failure Modes of Infilled Frames. Elect J Struct Eng, 11(1): 11-20

[38] Besnard G, Hild F, Roux S (2006) "Finite element" displacement fields analysis from digital images: application to Portevin-Le Châtelier bands. Exp Mech J 46 (6): 789-803

[39] Chrysotomou CZ (1991) Effects of degrading infill walls on the nonlinear seismic response of two-dimensional steel frame. Ph.D Thesis, Cornell University 
[40] Forquin P, Rota L, Charles Y, Hild F (2004) A method to determine the macroscopic toughness scatter of brittle materials. Int J of Fracture 125: 171-187

[41] Sutton MA, Li N, Garcia D, Cornille N, Orteu JJ, McNeill SR, Schreier HW, Li X, Reynolds AP (2007) Scanning Electron Microscopy for Quantitative Small and Large Deformation Measurements Part II: Experimental Validation for Magnifications from 200 to 10,000. Exp Mech 47 (6):.789-804.

[42] Sutton MA, McNeill SR, Helm JD, Chao YJ (2000) Advances in Two-Dimensional and ThreeDimensional Computer Vision. In Photomechanics, Springer, Berlin (Germany) Topics in Appl Phys 77: $323-372$

[43] Küntz M, Jolin M, Bastien J, Perez F, Hild F (2006) Digital image correlation analysis of crack behavior in a reinforced concrete beam during a load test. Canad J Civil Eng, 33: 1418-1425

[44] Bornert M, Chaix JM, Doumalin P, Dupré J-C, Fournel T, Jeulin D, Maire E, Moreaud M, Moulinec H (2004) Mesure tridimensionnelle de champs cinématiques par imagerie volumique pour l'analyse des matériaux et des structures. Inst Mes Métrol 4: 43-88

[45] Roux S, Hild F, Viot P, Bernard D (2008) Three dimensional image correlation from X-Ray computed tomography of solid foam. Comp. Part A 39(8):1253-1265

[46] Hild F, Raka B, Baudequin M, Roux S, Cantelaube F (2002) Multi-Scale Displacement Field Measurements of Compressed Mineral Wool Samples by Digital Image Correlation. Appl Optics IP 41 (32): 6815-6828

[47] Martínez M (2007) Análisis experimental del comportamiento de muros de mampostería confinada. Master thesis, University of Los Andes, Venezuela

[48] Guerrero N, (2007) Análisis Teórico-Experimental del Daño y del Pandeo Local en Estructuras de Ingeniería Civil. Doctoral thesis, University of Los Andes, Venezuela 